\title{
Boy with the Glue
}

\author{
Deeksha Elwadhi ${ }^{1}$
}

Received: 7 March 2017 / Accepted: 30 May 2017 /Published online: 19 June 2017

(C) Academic Psychiatry 2017

Artist's statement:

"There can be no keener revelation of a society's soul than the way in which it treats its children." This statement by one of the greats, Nelson Mandela, sums up the inspiration for my poem. I am a psychiatrist by profession, poet by passion, and human by choice. In my practice in the world's unhappier parts, I came across a 5-year-old boy brought from the street, lost in the world, abandoned by his parents, and hooked on inhalants. He could not tell his residential address, but could teach the postgraduate students the difference between huffing and puffing.

Seeing the lifeless eyes of this child made me feel ashamed of the dimensions and categories we fight over. With chemical attacks and sinking boats killing the children in alarming numbers, the ones who survive are our only hope-else, this generation will go down in history as the one that trampled all the saplings that were sowed.

There have been multiple academic papers regarding inhalant abuse and its varied side effects. This piece is just a humane ode to the inhumanity we, as medical practitioners, see and yet often refuse to register, the pain we know yet often refuse to feel, the humans we are yet often refuse to be. It is my attempt to express the desolation and dismay the boy may have felt as he faced the vicissitudes of life. I, in my privileged living, try to embark on a journey in the tiny shoes of this child with a play of words, seeking a bargain for this world's soul.

Deeksha Elwadhi

elwadhideeksha@gmail.com

1 Hamdard Institute of Medical Sciences and Research, New Delhi, India
Boy with the Glue

The eyes forlorn, hair disheveled, bewildered in my brain, numbed by the excruciating pain. The bland malady of existence, a loss of mere means of human sustenance.

I sit by the road in tatters, with the glue in a bottle. You walk down the road and just shun my sight. You pass by in cars at lightning speeds, Trying to fade me from your memory.

I am a thorn,

in the beautiful landscape.

I am the savage demon, chasing the offensive dragon. I symbolize the inhuman, making you cringe with revulsion.

But in truth, I am your own failure, staring lifelessly in your face.

Being crucified at the society's altar, I wonder where I faltered.

Is this me at wrong?

Or the world

I don't know what has stricken me, I don't know why you bother.

You are safe in your brick walls, and I am flying to heaven.

With one sniff and another puff, of the condemned magic sealed bottle

And as I look down, my dried eyes weep.

I know not what life is, I know not dignity.

All that I want from you, are alms full of humanity. 